\title{
EFFECT OF ADMINISTRATION OF ESSENTIAL AMINO ACIDS ON UTILIZATION OF DIETARY PROTEIN IN MALNUTRITION AMONG WAR CASUALTIES ${ }^{1}$
}

\author{
By KENDALL EMERSON, JR. ${ }^{2}$ AND OTTO F. BINKLEY 8 \\ (From the United States Naval Medical Research Unit No. 2)
}

(Received for publication October 8, 1945)

The appearance of severe malnutrition during convalescence in seriously wounded men is a frequent and troublesome complication of war casualties. These men frequently lose 50 to 60 pounds during the first few weeks after injury, and, as long as their wounds are still healing, this weight is regained only very slowly or not at all, in spite of an adequate and even high caloric diet.

A possible explanation for the inability of an apparently adequate diet to restore seriously injured persons to a normal nutritional status is afforded by a consideration of the rôle of the essential amino acids in protein metabolism. Since the classical experiments of Rose (1), it has been known that certain amino acids which cannot be synthesized by the body are essential for normal growth and development. No amount of nonessential amino acids can make up for a lack of the essential ones, and any protein lacking in any one of the essential amino acids cannot be utilized in protein anabolism, except to the extent that the missing amino acids are supplied from other exogenous sources. The regeneration of damaged tissue takes precedence over, and may occur at the expense of the metabolism of normal tissue. It is possible, therefore, that even on a normal protein intake the available supply of essential amino acids may be expended primarily on the restoration of damaged tissue, leaving an insufficient quantity of utilizable protein to meet the normal metabolic requirements of the remainder of the body.

According to this view, the supplementation of dietary protein by essential amino acids alone might succeed in meeting the excessive demands occasioned by wound repair and spare enough utilizable protein to restore and maintain a better

\footnotetext{
1 The Bureau of Medicine and Surgery of the Navy does not necessarily endorse the views or opinions which are expressed in this paper.

2 Lieutenant Commander, MC(S), U.S.N.R.

${ }^{3}$ Lieutenant (j.g.), H(S), U.S.N.R.
}

state of nutrition in the body as a whole. The increasing availability of synthetic amino acids makes the testing of this hypothesis highly feasible. The purpose of this report is to describe the effect of the intravenous administration of the ten amino acids, known to be essential for the rat (1), on the utilization of dietary protein by wounded men and to compare this effect quantitatively with that obtained by increasing the ordinary dietary intake of protein.

\section{MATERIALS AND METHODS}

Five subjects were selected for study, ranging in age from 19 to 38 years; all of whom had received severe penetrating wounds of the chest from one to two months previously. For experimental reasons, subjects were purposely selected who had recovered sufficiently to be able to maintain an adequate and reasonably constant dietary intake. All 5 of these patients, however, still showed very marked emaciation, were from 40 to 60 pounds underweight and for the most part were gaining weight only slowly or not at all on a high protein, high caloric intake. Four of the 5 still had draining thoracotomy tubes. In addition, 2 patients with acute infective jaundice were included in the study.

These subjects were divided into two groups. The first group, consisting of 3 wounded men, $\mathrm{Nm}, \mathrm{Ri}$, and $\mathrm{Cl}$, and one patient with hepatitis, Fl, was studied for 1 to 2 weeks on diets containing between 9 and 10 grams of protein nitrogen per day. The dietary nitrogen was then increased by from 25 to 100 per cent and the patients were observed for another 1 to 2 weeks. The second group of subjects, composed of 2 wounded men, $\mathrm{Haz}$ and $\mathrm{Hib}$, and 1 patient with hepatitis, Hap, was studied for 2 weeks on diets containing between 16 and 24 grams of protein nitrogen daily. They were then given intravenously 20 grams of the amino acid mixture described below, equivalent to 2.5 grams of nitrogen, daily for 6 days in addition to their diet, and the study was continued throughout this period and for 1 to 2 weeks longer.

The subjects were placed on weighed diets and the intake of protein, fat and carbohydrate was calculated from standard tables of food analysis. The calculation of the composition of the diets was rendered somewhat uncertain by the fact that they consisted largely of " $\mathrm{C}$ " rations and it is possible that the calculated nitrogen intakes were too high. This might account for the fact 
that some patients appeared to be "retaining" considerable amounts of nitrogen even during periods in which they were losing weight. Since all patients were eating the same food, however, and since the articles of the diet were extremely limited and repeated at frequent intervals, the error of calculating the nitrogen intake should affect all patients and all periods of study equally and should not influence the validity of comparing results on different patients receiving the same foodstuffs.

All urines and thoracotomy drainages were analyzed daily for total nitrogen by microdigestion and nesslerization. The urines were further analyzed for creatinine by a modification of Folin's method (2), and weekly aliquots were analyzed for urea plus ammonia by the hypobromite method (3) and for alpha amino acid nitrogen by the method of Van Slyke et al. (4). Nitrogen "retention" is calculated as the excess of the intake of protein and amino acid nitrogen over the nitrogen lost in the urine and thoracic drainage. This calculation fails to take into account the nitrogen lost in the feces and also in the sweat which may be considerable in the tropical climate where this study was carried out. These losses are relatively constant, however, in the absence of diarrhea or changes in environmental temperature, and for comparative purposes the excess of the intake over the urinary output of nitrogen may be considered to reflect accurately the true retention of nitrogen by the body. The daily loss of nitrogen from wound drainage rarely exceeded 0.5 gram, and was usually much less.

The synthetic amino acid mixture 4 utilized in this experiment was based on the proportions worked out by Whipple et al. (5) and had the following percentage composition.

$\begin{array}{lrcr}\text { dl Threonine } & 7 & \text { dl Phenylalanine } & 10 \\ \text { dl Valine } & 15 & \text { dl Methionine } & 13 \\ \text { dl Leucine } & 11 & 1 \text { Histidine } & 5 \\ \text { dl Isoleucine } & 10 & 1 \text { Arginine } & 5 \\ \text { 1 Lysine } & 11 & \text { Glycine } & 10 \\ \text { dl Tryptophane } & 3 & & \end{array}$

4 The amino acids were obtained from Merck and Co.

TABLE I

The effect of increasing the dietary intake of protein on the average daily urinary excretion and "retention" of nitrogen (Dotted line indicates period of increased intake)

\begin{tabular}{|c|c|c|c|c|c|c|}
\hline \multirow{2}{*}{ Patient } & \multirow{2}{*}{ Period no.* } & \multirow{2}{*}{ Body weight } & \multicolumn{3}{|c|}{ Nitrogen } & \multirow{2}{*}{ Remarks } \\
\hline & & & Intake & Output & "Retention" & \\
\hline $\mathrm{Nm}$. & $\begin{array}{c}1 \\
2 \\
\ldots \ldots \ldots \\
3 \\
4 \\
5 \\
6\end{array}$ & 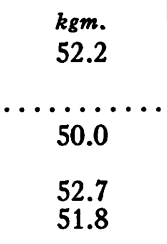 & $\begin{array}{c}\text { grams per day } \\
9.76 \\
10.64 \\
\ldots \ldots \ldots \ldots \ldots \\
16.77 \\
18.19 \\
17.13 \\
17.39\end{array}$ & $\begin{array}{c}\text { grams per day } \\
6.40 \\
3.33 \\
\ldots \ldots \ldots \ldots \\
4.90 \\
7.44 \\
4.06 \\
6.34\end{array}$ & $\begin{array}{c}\text { grams per day } \\
+3.36 \\
+7.31 \\
\ldots \ldots \ldots \ldots \\
+11.87 \\
+10.75 \\
+13.07 \\
+11.05\end{array}$ & $\begin{array}{l}\text { Chest wound. Thoracic } \\
\text { drainage nitrogen included } \\
\text { in output. }\end{array}$ \\
\hline $\mathrm{Ri}$. & $\begin{array}{c}1 \\
2 \\
\cdots \cdots \cdots \\
3 \\
4 \\
5 \\
6\end{array}$ & $\begin{array}{l}56.4 \\
\ldots \ldots \ldots . . \\
59.5 \\
\\
57.2 \\
57.2\end{array}$ & $\begin{aligned} & 11.57 \\
& 11.48 \\
& \ldots \ldots \ldots \ldots \\
& 18.05 \\
& 18.82 \\
& 19.33 \\
& 20.10\end{aligned}$ & 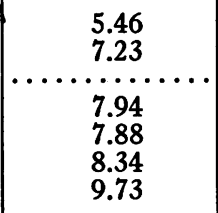 & 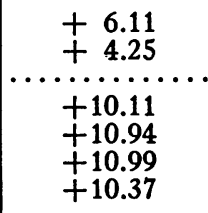 & Same as above \\
\hline $\mathrm{Cl}$. & 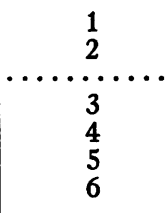 & $\begin{array}{c}58.2 \\
\ldots \ldots \ldots \\
56.8 \\
\\
59.1 \\
60.0\end{array}$ & $\begin{array}{c}11.31 \\
8.96 \\
\ldots \ldots \ldots \ldots \\
18.82 \\
21.71 \\
23.40 \\
21.94\end{array}$ & $\begin{array}{r}6.57 \\
6.17 \\
\ldots \ldots \ldots \ldots \\
7.56 \\
9.67 \\
8.53 \\
11.02\end{array}$ & $\begin{array}{c}+4.74 \\
+2.79 \\
\ldots \ldots \ldots \ldots \\
+11.26 \\
+12.04 \\
+14.87 \\
+10.92\end{array}$ & Same as above \\
\hline Fl. & 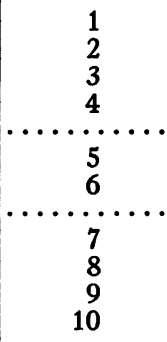 & $\begin{array}{c}68.2 \\
68.2 \\
\ldots \ldots \ldots \ldots \\
69.1 \\
\ldots \ldots \ldots \\
70.9 \\
72.3\end{array}$ & 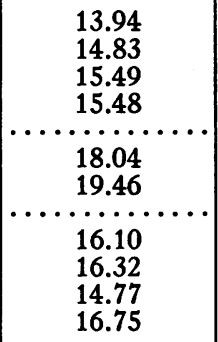 & $\begin{array}{c}10.02 \\
9.43 \\
10.33 \\
9.26 \\
\ldots \ldots \ldots \ldots . . . . . \\
10.04 \\
11.70 \\
\ldots \ldots . . \ldots \\
10.75 \\
9.45 \\
9.18 \\
12.56\end{array}$ & $\begin{array}{c}+3.91 \\
+5.40 \\
+7.01 \\
+6.22 \\
\ldots \ldots \ldots \\
+8.00 \\
+7.76 \\
\ldots \ldots .3 . \\
+5.35 \\
+6.87 \\
+5.59 \\
+4.19\end{array}$ & $\begin{array}{l}\text { Hepatitis. Patient showing } \\
\text { improvement in liver func- } \\
\text { tion. }\end{array}$ \\
\hline
\end{tabular}

* Consecutive 3-day periods. 
TABLE II

The effect of the intravenous administration of essential amino acids upon the urinary excretion and "retention" of nitrogen

\begin{tabular}{|c|c|c|c|c|c|c|c|}
\hline \multirow{2}{*}{ Patient } & \multirow{2}{*}{$\underset{\text { period }}{\text { no.** }}$} & \multirow{2}{*}{$\begin{array}{c}\text { Body } \\
\text { weight }\end{array}$} & \multicolumn{3}{|c|}{ Nitrogen } & \multirow{2}{*}{$\begin{array}{c}\text { Amino } \\
\text { acids } \\
\text { i.v. }\end{array}$} & \multirow{2}{*}{ Remarks } \\
\hline & & & Intake & Output & "Retention" & & \\
\hline Haz. & 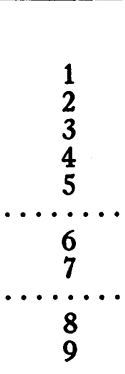 & $\begin{array}{c}\text { kgm. } \\
51.0 \\
50.0 \\
51.0 \\
\ldots \ldots \ldots \\
55.0 \\
\therefore \ldots \ldots \\
54.0\end{array}$ & $\begin{array}{c}\begin{array}{c}\text { grams per } \\
\text { day }\end{array} \\
17.97 \\
17.11 \\
17.71 \\
23.82 \\
22.59 \\
\ldots \ldots \ldots \\
23.99 \\
24.08 \\
\ldots \ldots \ldots \\
23.32 \\
20.62\end{array}$ & 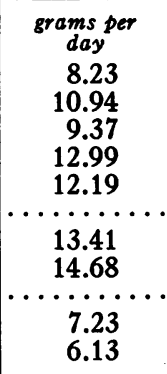 & 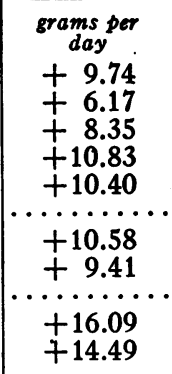 & $\begin{array}{c}\text { grams per } \\
\text { day } \\
0 \\
0 \\
0 \\
0 \\
0 \\
0 \\
\ldots \ldots \\
20 \\
20 \\
\ldots \ldots \\
0 \\
0\end{array}$ & $\begin{array}{l}\text { Chest wound. Thoracic drainage in- } \\
\text { cluded in output. } 2.5 \text { grams amino } \\
\text { acid nitrogen daily included in intake } \\
\text { for periods } 6 \text { and } 7 \text {. }\end{array}$ \\
\hline Hib. & 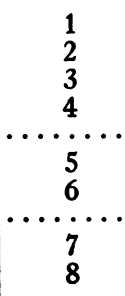 & $\begin{array}{c}55.0 \\
\\
60.0 \\
\ldots \ldots \ldots \\
61.5 \\
\cdots \cdots \\
63.0\end{array}$ & $\begin{array}{c}18.92 \\
19.11 \\
21.46 \\
23.45 \\
\ldots \ldots \ldots \ldots \\
18.84 \\
16.97 \\
\ldots \ldots \ldots \ldots \\
22.77 \\
22.23\end{array}$ & $\begin{array}{c}7.67 \\
8.27 \\
7.47 \\
12.82 \\
\ldots \ldots \ldots \ldots \\
7.43 \\
13.11 \\
\ldots \ldots \ldots \ldots \\
7.55 \\
5.41\end{array}$ & $\begin{array}{c}+11.25 \\
+10.84 \\
+13.99 \\
+10.63 \\
\ldots \ldots \ldots \\
+11.41 \\
+3.86 \\
\ldots \ldots \ldots \\
+15.22 \\
+16.82\end{array}$ & 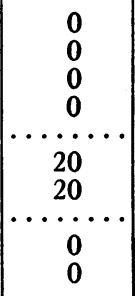 & $\begin{array}{l}\text { Chest wound. Thoracic drainage in- } \\
\text { cluded in output. } 2.5 \text { grams amino } \\
\text { acid nitrogen daily included in intake } \\
\text { for periods } 5 \text { and } 6 .\end{array}$ \\
\hline Hap. & $\begin{array}{r}1 \\
2 \\
3 \\
4 \\
\cdots \ldots \ldots \\
5 \\
6 \\
\ldots \ldots \\
7 \\
8 \\
9 \\
10\end{array}$ & $\begin{array}{c}58.2 \\
58.2 \\
\ldots \ldots \ldots \\
57.7 \\
\ldots \ldots \ldots \\
58.2 \\
59.1\end{array}$ & $\begin{array}{c}16.54 \\
15.40 \\
16.41 \\
15.12 \\
\ldots \ldots \ldots \ldots \\
17.37 \\
20.03 \\
\ldots . \ldots \ldots \\
14.68 \\
17.63 \\
15.27 \\
17.24\end{array}$ & $\begin{array}{c}10.57 \\
10.85 \\
12.78 \\
10.67 \\
\ldots \ldots \ldots \ldots \\
14.24 \\
10.24 \\
\ldots . \ldots \ldots \\
8.46 \\
8.90 \\
9.00 \\
9.20\end{array}$ & $\begin{array}{c}+5.97 \\
+4.55 \\
+3.63 \\
+4.45 \\
\ldots \ldots \ldots \\
+3.13 \\
+9.46 \\
\ldots \ldots . .2 \\
+6.21 \\
+8.73 \\
+6.27 \\
+8.04\end{array}$ & 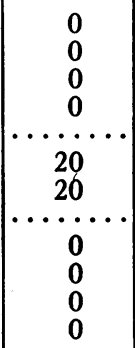 & $\begin{array}{l}\text { Hepatitis. Patient showed no im- } \\
\text { provement in liver function. } 2.5 \\
\text { grams amino acid nitrogen daily in- } \\
\text { cluded in intake for periods of } 5 \text { and } 6 .\end{array}$ \\
\hline
\end{tabular}

* Consecutive 3-day periods.

Twenty grams of this mixture were dissolved with the aid of heat in $500 \mathrm{ml}$. of physiological saline, filtered and autoclaved. This amount was administered intravenously daily for 6 days. The infusion was completed in a period of 20 to 30 minutes and no reactions were observed. The average daily nitrogen intake, urinary plus drainage tube output and "retention" have been calculated for consecutive 3-day periods and are presented in Tables I and II.

\section{RESULTS}

Within the range of nitrogen intakes studied, an increase in intake was uniformly accompanied by an increase in nitrogen "retention." In the 3 wounded men, $\mathrm{Nm}, \mathrm{Ri}$ and $\mathrm{Cl}$, when the protein nitrogen intake was nearly doubled (periods 3 to 6 , Table I) from 75 to 89 per cent of the extra nitrogen was retained. As might be expected in the presence of severe malnutrition, the excess of nitrogen intake over urinary excretion reached remarkably high values as the protein intake was increased. In the patient with hepatitis, Fl, when the dietary nitrogen was increased by 25 per cent, approximately 30 per cent of the added nitrogen was retained (periods 5 and 6 , Table I).

A consideration of the effect of supplementing dietary protein by the intravenous administration of the 10 essential amino acids (Table II) reveals two points of interest. First, the effect appeared to be a delayed one. In neither $\mathrm{Haz}$ nor $\mathrm{Hib}$ was there any increase in nitrogen "retention" during the 6 days of amino acid administrations (periods 6 and 7, Table II). In the case of Hib this might have been due to the fact that his thoracotomy drainage tube became obstructed during 
this period and he was running a fever of 101 to $102^{\circ}$ with consequent loss of appetite, decreased protein intake and increased nitrogen catabolism. In the patient with hepatitis, Hap, an increased retention of nitrogen first became apparent during the second 3-day period of amino acid administration (periods 5 and 6, Table II). In all 3 subjects a fall in urinary nitrogen excretion and rise in nitrogen "retention" occurred in the week after the amino acid administration. This was especially marked in the 2 wounded men, but in the patient with hepatitis this increased nitrogen retention persisted for 2 weeks after cessation of amino acid administration.

The second point of interest is the fact that the magnitude of the increase in nitrogen retention occurring during the latter half of the period of amino acid administration in Hap, and during the subsequent week in all 3 subjects was from 2 to 3 times the amount of nitrogen, either as protein or amino acids, by which the intake had been increased (Table III). This is in sharp contrast to the effect of increasing the dietary protein alone, where the magnitude of the increased nitrogen retention never exceeded the amount of the increase in intake. Moreover, when the level of nitrogen intake was approximately the same in both groups, the absolute values for nitrogen "retention" were significantly higher in the subjects who had received amino acids than in those who had not. It would appear that increasing the supply of essential amino acids had increased the utilization of dietary protein far more than could be accounted for merely by the additive effect of the amino acid nitrogen.

A marked increase in body weight was shown by Haz during the period of amino acid administration. The other wounded man, Hib, was already showing a rapid gain during the pre-treatment stage. During amino acid therapy while the patient was running a fever as a result of his wound infection, his rate of gain in weight diminished, as might be expected, but did not cease. The 3 subjects, $\mathrm{Cl}, \mathrm{Ri}$, and $\mathrm{Nm}$, showed a loss of weight on the diets containing 9 to 11 grams of nitrogen. This loss was regained when the nitrogen intake was markedly increased, but they showed little or no further gain in weight during the period of study. The 2 patients with hepatitis were not exactly comparable in that $\mathrm{Fl}$, who did not receive amino acids was showing steady improvement in liver function and also gain in weight during the period of study. On the other hand, Hap, who received amino acids, showed no improvement in liver function while under observation. In spite of this he started gaining weight during the week following amino acid therapy for the first time since the onset of his illness.

A study of some of the nitrogenous constituents of the urine revealed that the intravenous administration of amino acids caused no consistent change in the excretion of urea. From 10 to 30 per cent of the administered amino acids were excreted in the urine (Table IV). These may have been some of the unnatural isomers contained in the mixture, which are slowly or incompletely utilized. No greater loss of amino acids in the urine was noted in the patient with hepatitis than in the 2 wounded men. This is rather surprising in view of the fact that this patient showed a definite decrease in his tolerance

TABLE III

A comparison of the average daily increase in nitrogen "retention" following an increase in dietary protein intake and following administration of the essential amino acids

\begin{tabular}{|c|c|c|c|c|c|}
\hline Patient & $\begin{array}{c}\text { Total increase } \\
\text { in nitrogen } \\
\text { intake }\end{array}$ & $\begin{array}{l}\text { Increase in } \\
\text { nitrogen } \\
\text { "retention" }\end{array}$ & $\begin{array}{c}\text { Increased } \\
\text { "retention" } \\
\begin{array}{c}\text { Increased } \\
\text { intake }\end{array}\end{array}$ & $\begin{array}{c}\text { Method } \\
\text { of } \\
\text { treatment }\end{array}$ & Method of calculation \\
\hline $\begin{array}{l}\mathrm{Nm} . \\
\mathrm{Ri} . \\
\mathrm{Cl} \text {. } \\
\mathrm{Fl} .\end{array}$ & $\begin{array}{c}\text { grams per day } \\
7.17 \\
7.55 \\
11.27 \\
3.76\end{array}$ & $\begin{array}{c}\text { grams per day } \\
6.35 \\
5.62 \\
8.50 \\
1.09\end{array}$ & $\begin{array}{l}0.89 \\
0.74 \\
0.75 \\
0.29\end{array}$ & $\begin{array}{l}\text { increased diet } \\
\text { same } \\
\text { same } \\
\text { same }\end{array}$ & $\begin{array}{l}\text { Periods } 3 \text { to } 6 \text { minus } 1 \text { and } 2 \text {, Table } I \text {. } \\
\text { same } \\
\text { same } \\
\text { Periods } 5 \text { and } 6 \text { minus } 1 \text { to } 4 \text {, Table } I \text {. }\end{array}$ \\
\hline $\begin{array}{l}\text { Haz. } \\
\text { Hib. } \\
\text { Hap. }\end{array}$ & $\begin{array}{l}2.12 \\
1.76 \\
1.10\end{array}$ & $\begin{array}{l}6.19 \\
4.34 \\
2.84\end{array}$ & $\begin{array}{l}2.92 \\
2.47 \\
2.58\end{array}$ & $\begin{array}{l}\text { amino acids } \\
\text { same } \\
\text { same }\end{array}$ & $\begin{array}{l}\text { Periods } 8 \text { and } 9 \text { minus periods } 1 \text { to } 5 \text {, Table II. } \\
\text { Periods } 7 \text { and } 8 \text { minus periods } 1 \text { to } 4 \text {, Table II. } \\
\text { Periods } 6 \text { to } 10 \text { minus periods } 1 \text { to 4, Table II. }\end{array}$ \\
\hline
\end{tabular}


TABLE IV

The effect of the intravenous administration of synthetic amino acids on the urinary excretion of alpha amino nitrogen and on the proportion of the total urinary nitrogen excreted as urea

\begin{tabular}{|c|c|c|c|c|c|c|}
\hline \multirow{2}{*}{ Patient } & \multirow{2}{*}{ Date } & \multicolumn{4}{|c|}{ Alpha-amino acid nitrogen } & \multirow{2}{*}{$\begin{array}{l}\text { Urea nitrogen } \\
\text { Percentage of } \\
\text { total urinary } \\
\text { nitrogen }\end{array}$} \\
\hline & & Intake & $\begin{array}{l}\text { Urinary } \\
\text { output }\end{array}$ & $\begin{array}{c}\text { Excess loss } \\
\text { in urine }\end{array}$ & $\begin{array}{l}\text { Percentage of in- } \\
\text { take lost in urine }\end{array}$ & \\
\hline \multirow[t]{3}{*}{ Haz. } & Aug. 9 to 14 & $\begin{array}{c}\text { grams per day } \\
0\end{array}$ & $\begin{array}{c}\text { grams per day } \\
0.111\end{array}$ & grams per day & per cent & per cent \\
\hline & Aug. 15 to 20 & 2.090 & 0.648 & 0.524 & 25 & 72.4 \\
\hline & Aug. 21 to 28 & 0 & 0.137 & & & 87.2 \\
\hline \multirow[t]{3}{*}{ Hib. } & Aug. 9 to 14 & 0 & 0.117 & & & 82.5 \\
\hline & Aug. 15 to 20 & 2.090 & 0.369 & 0.262 & 12.5 & 88.0 \\
\hline & Aug. 21 to 28 & $\ddot{0}$ & 0.098 & & & 80.8 \\
\hline \multirow[t]{3}{*}{ Hap. } & $\begin{array}{l}\text { July } 28 \\
\text { July } 30\end{array}$ & $\begin{array}{l}0 \\
0\end{array}$ & $\begin{array}{l}0.098 \\
0.085\end{array}$ & & & $\begin{array}{l}84.8 \\
69.5\end{array}$ \\
\hline & $\begin{array}{lr}\text { July } & 31 \\
\text { Aug. } & 5 \\
\text { Aug. } & 6\end{array}$ & $\begin{array}{l}2.090 \\
2.090 \\
2.090\end{array}$ & $\begin{array}{l}0.248 \\
0.151 \\
0.372\end{array}$ & 0.155 & 7.5 & $\begin{array}{l}7 \ldots .2 \\
72.2 \\
86.1 \\
93.8\end{array}$ \\
\hline & Aug. 7 & 0 & 0.122 & & & 85.5 \\
\hline
\end{tabular}

to amino acids, indicative of liver damage. His plasma alpha amino acid level rose to $11.51 \mathrm{mgm}$. per $100 \mathrm{ml}$. immediately after the infusion of 20 grams of amino acids and failed to reach the preinjection level of $3.74 \mathrm{mgm}$. per $100 \mathrm{ml}$. after 90 minutes. It would seem unlikely, therefore, that the loss of amino acids in the urine of the wounded men with presumably normal liver function was due primarily to failure of storage or metabolism by the liver.

\section{DISCUSSION}

From the foregoing data it is apparent that the addition of an excess of all the essential amino acids to a normal diet increases the utilization of dietary protein by individuals who are in a state of malnutrition. Such a result is anticipated from Rose's demonstration of the necessity of the essential amino acids for normal growth and tissue metabolism, which leads to the concept that the nutritional efficiency of any protein is limited by its content of these amino acids. Thus a diet normally adequate in protein may be inadequate in its content of essential amino acids to supply the excessive and preferential demands for the restoration of damaged tissue and still have enough left over to supply the normal metabolic needs of the body. Even though an excess of the nonessential amino acids may remain unused after the withdrawal of the essential ones, they are no longer available for protein anabolism and a state of generalized malnutrition will ensue. When the supply of essential amino acids is increased, a larger proportion of the dietary protein is made available for use in the metabolism of the body as a whole. From the data presented it might be estimated that for each essential amino acid administered somewhere between 2 and 3 nonessential amino acids become available for incorporation into body protein.

The reason for the delay in the appearance of the effect of the added amino acids on protein utilization, or for the prolongation of this effect for 1 to 2 weeks after cessation of their administration, is not at present clear. It seems possible that a portion of the administered amino acids may be stored in the liver as a reserve which continues to be available for protein formation over a considerable period of time. Further work must be done on a larger series of cases in order to define more exactly the time relationships involved between the administration of amino acids and the onset of their effect on protein utilization. If the dietary protein were relatively more defi- 
cient in some essential amino acids than in others, which is probably the case even in proteins of high biological value, the addition of only certain selected essential amino acids might have as great an effect on protein utilization as all 10 of them. Obviously a great deal more work must be done to determine the best possible combination of the essential amino acids to use, but it is evident that the parenteral use of synthetic amino acids is a practical and useful procedure and has many advantages over other types of protein substitution therapy.

\section{SUMMARY AND CONCLUSIONS}

1. A synthetic mixture of the 10 amino acids shown to be essential for the rat has been administered intravenously to 2 wounded men and 1 patient with acute infective jaundice, who were all in a severe state of malnutrition. At the same time, these subjects were receiving a high protein, high caloric diet.

2. For a period of 1 to 2 weeks following the amino acid administration all 3 subjects exhibited a marked increase in nitrogen utilization which exceeded by from 2 to 3 times the total increase in nitrogen intake.

3. These results were compared with the effect of increasing dietary protein in comparable experimental subjects. In no case did the increase in nitrogen utilization exceed the increase in protein nitrogen intake.

4. The parenteral administration of synthetic amino acids is a practicable and valuable form of protein substitution therapy.

Grateful acknowledgment is made to Major Warriner Woodruff, MC, A.U.S., and Captain H. R. Holmes, MC, A.U.S., for making their patients available to us; to 1st Lt. Florence Nelson, A.U.S., and 2nd Lt. Emma Loetterle, A.U.S., for their aid in handling the diets, and to Cyril Laffoon, PhM1c, U.S.N.R., Packrad Krekorian, PhM1c, U.S.N.R., and William Becker, PhH2c, U.S. N.R., for their technical assistance.

\section{BIBLIOGRAPHY}

1. Rose, W. C., The nutritive significance of the amino acids. Physiol. Rev., 1938, 18, 109.

2. Folin, O., On the determination of creatinine and creatine in blood, milk and tissues. J. Biol. Chem., $1914,17,475$.

3. Peters, J. P., and Van Slyke, D. D., Quantitative Clinical Chemistry. Vol. II. Page 379. Williams and Wilkins Co., Baltimore, 1932.

4. Van Slyke, D. D., MacFadyen, D. A., and Hamilton, P. B., The gasometric determination of amino acids in urine by the ninhydrin-carbon dioxide method. J. Biol. Chem., 1943, 150, 251.

5. Madden, S. C., Woods, R. R., Shull, F. W., Remington, J. H., and Whipple, G. H., Tolerance to amino acid mixtures and casein digests given intravenously. J. Exper. Med., 1945, 81, 439. 